\title{
LOCOMOTOR ACTIVITY OF PROFESSIONAL FOOTBALL REFEREES
}

Manilo Y.V.

Vinnitsa State Pedagogical University

Annotation. Purpose: To study the structure of the motor activity of foreign (European) football referees qualifications and Ukrainian arbitrators (Premier League, the first, second league). The objectives of the study was to determine the amount and direction of the motor activity of soccer referees. Also perform a comparative analysis of the motor activity of football referees of different qualifications in Europe and Ukraine. Material: The study involved 38 referees - soccer referees first, second, of the Premier League with the different regions of Ukraine, as well as foreign arbitrators FIFA. Results: It was found that in the period of the motor activity of the arbitrator was walking - $13.0 \%$ of the total distance when moving, running at a moderate pace $-67.4 \%$, accelerating $-16.7 \%$, jumps $-2.9 \%$. Average per match referee overcomes distance $8970.2 \mathrm{~m}$ : foreign arbitrators - 12,030.0 m., Arbitrators Premier League - $9292.5 \mathrm{~m} ., 1$ league 7530.0 m., 2 leagues - 7028.3 m. Ukrainian Premier League referees are inferior to move moderate jogging foreign arbitrators FIFA respectively - 6,425.0 $\mathrm{m}(69.1 \%)$ and $9615.3 \mathrm{~m}(79.9 \%)$. Conclusions: The results of the research showed that the magnitude of motor activity during football matches in professional arbitrators may be different. It depends on their physical fitness Championship (competition), the league, the level of the teams playing, the nature of the intensity of the match. The arbitrator must remain near the gaming moments to control them and prevent possible confrontation.

Key words: locomotor activity, football, football referees, football field, match, playing moment, championship.

\section{Introduction}

Football is one of the most mass kinds of sports, which also requires mass training of qualified referees for matches of professional teams. For taking correct and important decisions being at optimal distance from game situation referee shall always be in perfect physical condition $[4,5,8,11]$.

Thus, football referee shall be able to quickly and frequently move. Most of referees demonstrate reduction of motion activity during football matches, depending on temp of game, on teams, condition of football field and referee's physical fitness $[1,3,16]$.

In connection with increased speed in football matches, temp of game also increased and referee can not always be in optimal position, especially if he does not recognize football players' intentions, does not foresee next stage of attack's development [2, 6, 7].

Referee, as well as football player, shall have perfect physical fitness. He shall be constantly near game situation, to control it in compliance with football rules, prevent from different confrontations, psychologically influence on football players $[10,17]$.

The research has been fulfilled in compliance with "Combined plan of scientific-research works in sphere of physical culture and sports for 2011-2015" of State committee on youth problems, sports and tourism of Ukraine by topic "Theoretical-methodic principles of individualization in physical education and sports" (state registration number 0112U002001).

\section{Purpose, tasks of the work, material and methods}

The purpose of the work is to analyze the structure of motion functioning of highly qualified foreign (European) football referees as well as Ukrainian ones of Prime, first and second leagues.

The tasks of the research were to determine the scope and orientation of football referees' motion functioning and to fulfill comparative analysis of motion functioning indicators of different qualifications' referees from Europe and Ukraine.

The methods and material of he research: analysis of literature sources, pedagogic observations, timing of motion functioning, video-recording, methods of mathematical statistic. 12 football referees of first, second, Prime leagues of Ukraine participated in the research; besides, we conducted analysis of functioning of foreign referees of FIFA, who participated in European cup matches of. In total, we analyzed 38 matches, in which referees of different qualification participated.

For evaluation of every referee's motion functioning in national matches (Prime, first and second leagues) and in matches at European level we determined distances of walking, moderate running, accelerations and entered the data in records of the research. In the course of match kinds of referee's travelling constantly changed from moderate running to accelerations and intensive jerks.

\section{Results of the research}

Physical fitness is an important part of referee's general training for competitions. It facilitates progressing of motion potential, connected with improvement of organism's functional potentials, with comprehensive physical development $[9,12]$.

The level of referees' physical fitness shall also be constantly perfected. It is connected with the fact that in his highly intensive activity referee shall be near game situations (considering his location with diagonal system of refereeing), and take optimal for taking decisions position [13]. 
Modern football referee can conduct match successfully only if his own functional state is perfect. Accelerations and jerks are followed by moderate running (forward and backward), walking, stops, and are fulfilled in different directions, with different temp and speed. Such activity is connected with certain physical loads and is accompanied by significant functional changes in metabolism, respiratory and blood circulation systems [14, 15].

The research resulted in the facts that highly qualified referees (foreign referees from FIFA, Ukrainian Prime league referees) during one match cover distance, in average, of 10600 meters and their mean heart beat rate is $150-$ 170 b.p.m.

Table 1

Mean indicators of motion functioning of professional football referees in the course of matches

\begin{tabular}{|c|c|c|c|c|c|}
\hline \multirow{2}{*}{$\begin{array}{l}\text { Referees, } \\
\text { leagues }\end{array}$} & \multicolumn{4}{|c|}{ Motion functioning $(\bar{x} \pm s)$} & \multirow[b]{2}{*}{$\begin{array}{l}\text { Total, meters, } \% \\
\text { from total scope }\end{array}$} \\
\hline & $\begin{array}{c}\text { Walking, } \\
\text { meters \% from } \\
\text { total scope }\end{array}$ & $\begin{array}{c}\text { Moderate } \\
\text { running, meters, } \\
\% \text { from total } \\
\text { scope }\end{array}$ & $\begin{array}{l}\text { Accelerations, } \\
\text { meters, } \% \text { from } \\
\text { total scope }\end{array}$ & $\begin{array}{l}\text { Jerks, meters, } \\
\% \text { from total } \\
\text { scope }\end{array}$ & \\
\hline $\begin{array}{l}\text { Foreign referees, } \\
\text { FIFA }(\Pi=26)\end{array}$ & $\begin{array}{c}1125.3 \pm 24.1 \\
9.4 \%\end{array}$ & $\begin{array}{c}9615.3 \pm 111.4 \\
79.9 \%\end{array}$ & $\begin{array}{l}973.7 \\
\pm 21.1 \\
8.1 \%\end{array}$ & $\begin{array}{l}315.7 \\
\pm 6.5 \\
2.6 \%\end{array}$ & $\begin{array}{c}12030.0 \\
+163.1 \\
100 \%\end{array}$ \\
\hline $\begin{array}{c}\text { Prime } \\
\text { league }(\Pi=4)\end{array}$ & $\begin{array}{c}1057.5 \pm 84.1 \\
11.4 \%\end{array}$ & $\begin{array}{c}6425.0 \pm 415.9 \\
69.1 \%\end{array}$ & $\begin{array}{r}1587.5 \\
+137.2 \\
17,1 \% \\
\end{array}$ & $\begin{array}{c}222.5+48.6 \\
2.4 \%\end{array}$ & $\begin{array}{c}9292.5 \pm 685.8 \\
100 \%\end{array}$ \\
\hline $\begin{array}{l}1 \text { league } \\
(\Pi=2)\end{array}$ & $\begin{array}{c}1270.0 \\
+486.7,16.9 \%\end{array}$ & $\begin{array}{c}4302.5 \pm 1101.8 \\
57.1 \%\end{array}$ & $\begin{array}{r}1750 \\
+177.0 \\
23.2 \%\end{array}$ & $\begin{array}{c}207.5 \pm 57.5 \\
2.8 \%\end{array}$ & $\begin{array}{c}7530.0 \pm 1823.0 \\
100 \%\end{array}$ \\
\hline $\begin{array}{c}2 \text { league } \\
(\Pi=6)\end{array}$ & $\begin{array}{c}1005.8 \pm 204.4 \\
14.3 \%\end{array}$ & $\begin{array}{c}4453.3 \pm 1154.0 \\
63.4 \%\end{array}$ & $\begin{array}{r}1292.5 \\
+279.2 \\
18.4 \%\end{array}$ & $\begin{array}{c}276.7 \pm 144.1 \\
3.9 \%\end{array}$ & $\begin{array}{c}7028.3 \pm 1781.7 \\
100 \%\end{array}$ \\
\hline $\begin{array}{l}\text { Total } \\
(\Pi=38)\end{array}$ & $\begin{array}{c}1114.6 \pm 199.8, \\
13.0 \%\end{array}$ & $\begin{array}{c}6199.0 \pm 695.8 \\
67.4 \%\end{array}$ & $\begin{array}{r}1400.9 \\
+153.6 \\
16.7 \% \\
\end{array}$ & $\begin{array}{c}255.6 \pm 64.2 \\
2.9 \%\end{array}$ & $\begin{array}{c}8970.2 \pm 1113.4 \\
100 \%\end{array}$ \\
\hline
\end{tabular}

Correlations of football referees' motion functioning are as follows: waking was $-13.0 \%$ from total distance of travelling, moderate running $-67.4 \%$, accelerations $-16.7 \%$, jerks $-2.9 \%$ (see table 1 , fig. 1 ).

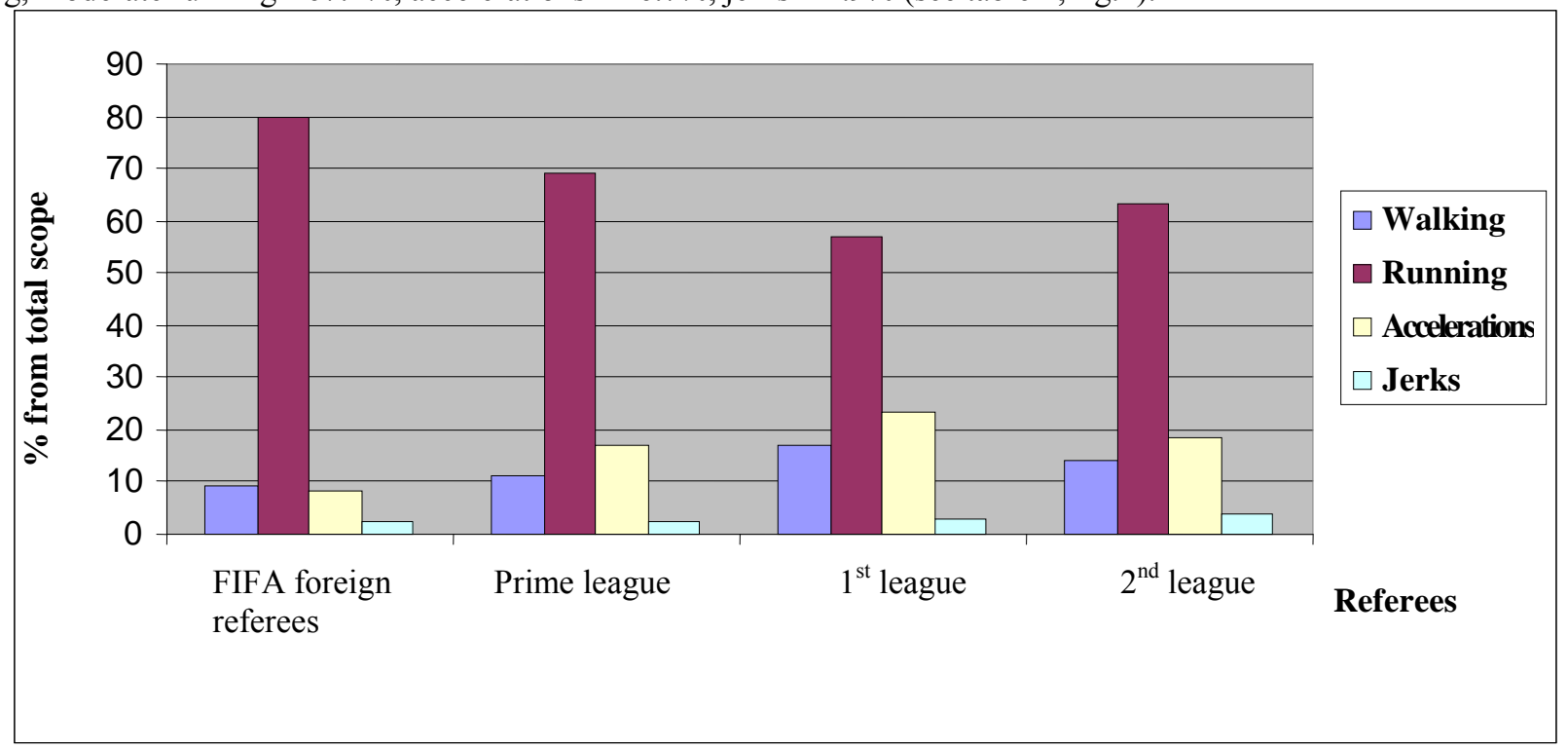

Fig. 1.Comparison of mean indicators of professional football referees' motion functioning in the course of different levels' matches

Besides, we determined that foreign referees from FIFA are far superior in comparison with Ukrainian colleagues form Prime, first and second leagues by scope of travelling on football field. In average, referee covers distance of 8970.2 meters during match. Having calculated all kinds of motion functioning, we determined that foreign referees in total cover 12030 meters during match, Prime league referees -9292.5 meters, $1^{\text {st }}$ league referees- 7530.0 meters, second - 7028.3 meters (see table 1). Besides, foreign referees use walking to less extent -1125.3 meters 
(9.4\%) than their Ukrainian colleagues: Prime league - 1057.5 meters (11.4\%), first league -1270.0 meters (16.9\%) and second league - 1005.8 meters (14.3\%) (see fig.1). Ukrainian referees of Prime league yield to FIFA referees also in moderate running accordingly - 6425.0 meters $(69.1 \%)$ and 9615.3 meters (79.9\%). Foreign referees use accelerations to less extent -973.7 meters $(8.1 \%)$ than their Ukrainian colleagues (see table 1, fig.1).

\section{Conclusions}

1. Results of the researches showed that motion activity of professional referees can be different during football matches and depends on their physical fitness, level of championship (competition), league, level of teams and match's intensity.

2. The more football referee use such kinds of motion functioning as walking, moderate running, accelerations and jerks the closer he will be to situation of rules' violation taking, with it, favorable, optimal position, and the more effective refereeing will be.

3. Foreign referees from DFIFA have higher physical fitness than Ukrainian professional referees. The further researches of this problem will be oriented on working out of model of football referee's fitness.

\section{References}

1. Abdula A.B. Pedagogika, psihologia ta mediko-biologicni problemi fizicnogo vihovanna i sportu [Pedagogics, psychology, medical-biological problems of physical training and sports], 2007, vol.5, pp. 85-87.

2. Bogino A.V., Kazarina E.A. Teoriia i praktika futbola [Theory and practice of football], 2004, vol.2, pp. 1215.

3. Budogosskij A.D. Organizacionno-pedagogicheskie aspekty postroeniia processa professional'noj podgotovki futbol'nykh arbitrov nachal'noj kategorii [Organizational and pedagogical aspects of the construction process of training of football referees in the initial category], Cand. Diss., Moscow, 2008, 26 p.

4. Vikhrov K.L. Kompan'on futbol'nogo arbitra [Companion soccer referee], Kyiv, Combi LTD, 2006,352 p.

5. Zuev V.N. Sportivnyj arbitr [Sports referee], Moscow, Soviet sport, 2004, 394 p.

6. Kostiukevich V. M. Futbol [Football], Vinnitsa, JSC "Vinobl printing", 1997, 260 p.

7. Kostiukevich V. M. Organizaciia i provedennia zmagan' iz sportivnikh igor [Organizing and conducting sports competitions], Vinnitsa, Glider, 2005, 216 p.

8. Petrov V.D., Abdula A.B. Fizicheskaia podgotovka futbol'nykh arbitrov [Physical training of football referees], Kharkov, 2007, 96 p.

9. Seluianov V. N., Sarsaniia S.K., Sarsaniia K.S. Fizicheskaia podgotovka futbolistov [Physical training players], Moscow TBT Division, 2004, 192 p.

10. Spirin A. N. Budogosskij A.D. Sudejstvo [Refereeing], Moscow, 2003, 273 p.

11. Turbin E.A. Formirovanie special'nykh navykov futbol'nikh arbitrov nachal'noj podgotovki [Formation of special skills soccer referee initial training], Cand. Diss., Malahovka, 2009, 243.

12. Uilmor Dzh., Kostill D. Fiziologiia sporta i dvigatel'noj aktivnosti [Physiology of sport and motor activity], Kiev, Olympic Literature, 1997, 504 p.

13. Khusainov G. Teoriia i praktika futbola [Theory and practice of football], 2001, vol.21, pp. 21-23.

14. Shalenko V.V., Perevoznik V.I. Pidgotovka arbitriv u futboli [Training referees in football], Hark, KSAPC, 2001, $92 \mathrm{p}$.

15. Helsen W. Performance training in football refereeing. UEFA Referee Commiti, 2005, $200 \mathrm{p}$.

16. Krustrup P., Mohr M, Bangsbo J. Activity profile and physiological demands of top class soccer assistant refereeing in relation to training status. Journal Sports Sciences. 2002, vol.20, pp. 861-871.

17. Sampaio J., Ganeira M., Ibez S., Lorenzo A. Discriminant analysis of game-related statistics between basketball guards, forwards and centrec in three professional leagues. Europian Journal of Sports Science, 2006, vol. 6, pp. 173-178. 


\section{Information about the author:}

Manilo Y.V.: ORCID: http://orcid.org/0000-0002-8374-3912; refmanilo@mail.ru; Vinnitsa State Pedagogical University; Ostrogskogo str. 32, Vinnitsa, 21100, Ukraine.

Cite this article as: Manilo Y.V. Locomotor activity of professional football referees. Physical education of students, 2014, vol.6, pp. 37-40. doi:10.15561/20755279.2014.0607

The electronic version of this article is the complete one and can be found online at: http://www.sportpedu.org.ua/html/arhive-e.html

This is an Open Access article distributed under the terms of the Creative Commons Attribution License, which permits unrestricted use, distribution, and reproduction in any medium, provided the original work is properly cited (http:// creativecommons.org/licenses/by/3.0/deed.en)

Received: 10.06 .2014

Published: 30.06 .2014 